\title{
Significance of cutting process parameters as related to improving dynamic state of roadheader and minimizing power consumption
}

\begin{abstract}
The process of mechanical excavation, especially that of hard rocks, is very dynamic. This results in heavy loads and vibrations in the cutting system of a roadheader, the drive units of the mechanism related to the excavation process, and the load-carrying structure of the roadheader. The ad verse dynamic state that stems from excessive dynamic loads or even overloading will cause a high failure rate in the roadheader and low efficiency of its operational process (high energy consumption, low productivity), thus leading to high costs of driving tunnels using the mining method involving roadheaders. This article presents selected results of extensive computer studies on the impact of cutting process conditions on the dynamic state of a boom-type roadheader equipped with transverse cutting heads and on the energy consumed during the excavation process. On one hand, cutting process conditions result from properties of an excavated rock material and, on the other hand, from process parameter values set up during the excavation of tunnels. Simulation studies conducted using experimentally verified mathematical models made it possible to identify relationhips that link dynamic loads of the body of a boom-type roadheader and energy needed for mining to the cutting process parameters of rocks with different compressive strengths. The regulation properties obtained in this way show the possibility of reducing dynamic loads of the roadheader through the proper control of cutting process parameters, including the angular speed of the cutting heads. By equipping the roadheader with a cutting head inverter drive system, it is possible to adjust the speed to the cutting process conditions by changing the supply voltage frequency of an asynchronous motor installed in the roadheader's cutting system.
\end{abstract}

Key words: roadheader, cutting process, dynamics, simulation studies

\section{INTRODUCTION}

Research and development work on the automation (robotization) of tunnel excavation in underground mining and civil construction has been conducted for many years $[1-3,8,9,16,17]$. The purpose of mining work robotization is to limit or even eliminate the presence of man at the mining site, which should lead to an improvement in worker safety. Optimization of the work process, which is possible due to the automated control of machines, will ensure an in- creased efficiency in the work and a better use of the technical potential of the machinery and devices. This in turn will allow for a higher productivity (driving progress) and lower cost of this type of mining work to be achieved. The use of autonomous mining robots will cause people's involvement to be limited to the remote monitoring of the machinery and device operation and overseeing the correctness of the work processes carried out by them, alternatively - remote control of only a few technological operations as a teleoperator [10-13]. 
Boom-type roadheaders are used for driving roadways in underground coal mines and the mining of other rocks with properties similar to coal (mining of salt, potassium, and metal ores such as copper [18]). They are also used for boring communication tunnels and other underground engineering objects such as underground garages or tunnels in water power plants (though to a limited extent) [14, 19, 20]. An important issue related to the work automation of this type of machine is the proper (optimal) control of the cutting process in a working environment that changes over time. This volatility is the result of the geological structure of the rock mass at the mining site - the variable workability of rocks at the cross-sections of tunnels due to the layered structure of the rock mass and variable workability of the rocks over the length of roadways or a tunnel.

The cutting system of a boom-type roadheader is equipped with cutting heads at the end of a movable boom that are relatively small compared to the dimensions of the heading face. Excavation is usually carried out in parallel to the surface of a floor [11]. When deflecting the boom in this plane, the cutting heads make cuts with a particular cross-section area size that correlates to the size of web of cut $z$ and cut height $h$ (Fig. 1). The cutting process is conducted with a certain speed correlated to the angular speed of the cutting heads and their advancement speed $v_{O W}$.

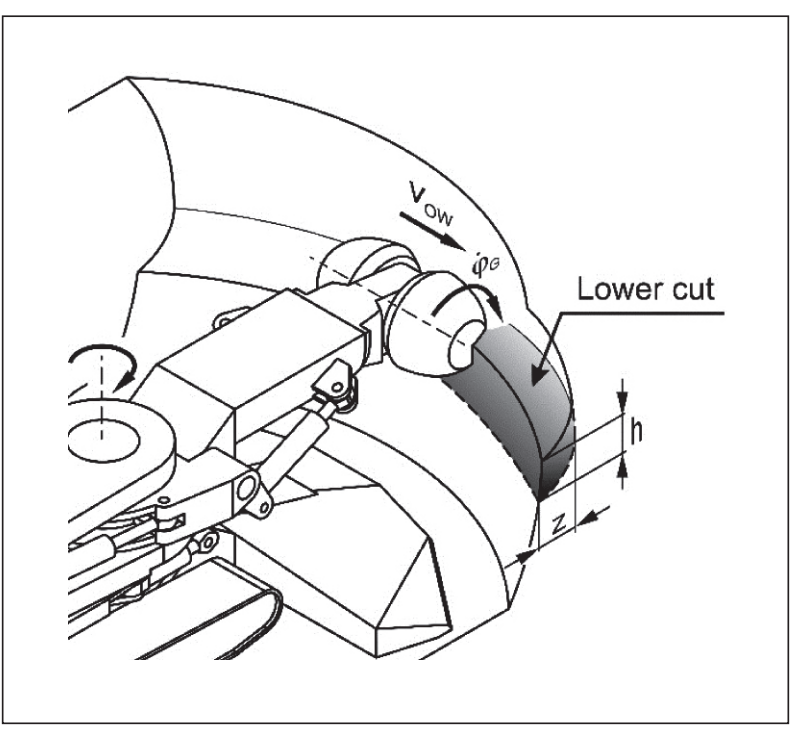

Fig. 1. Process parameters of cutting heading face with boom-type roadheader: $z$ - web of cut, $h$ - cut height, $\dot{\varphi}_{G}$ - angular speed of cutting head, $v_{O W}-$ advancement speed of cutting heads
In those boom-type roadheaders that are already in use, an operator manually inputs the web of the cut, cut height, and cutting head advancement speed parameters from his workstation located on a roadheader (and in some cases from a remote workstation). Therefore, it is not possible to adjust these values in an optimal manner. In the cutting system, the cutting head angular speed (correlated to the motor angular speed and gear ratio of a gear transmission) is constant. In some boom-type roadheader designs, it is possible to select one of two cutting head angular speeds - due to switching a two-speed motor or a two-speed gearbox. However, it is impossible to adjust (control) this value to the process conditions during excavation. It would be possible to implement steps of adjustment of the cutting heads' angular speed by using a frequency inverter in the drive of a roadheader's cutting system.

According to the experimental and computer studies results described [4, 7], the reduction of dynamic loads and vibrations in the roadheader's drive units and its load-carrying structure as well as the minimization of power and energy consumption require the appropriate control of parameter values during the cutting process. However, this is only possible after equipping the roadheader with an automatic control system. The starting point for developing an effective operating algorithm of such a system is defining the dynamic state of the roadheader during the cutting process with different associations of parameter values for this process. Basically, these types of studies are only possible with the use of adequate simulation models. They are the basis for making conclusions in regards to the reduction of dynamic loads, vibrations, and energy consumption.

The article describes selected results of extensive simulation studies conducted with the use of experimentally verified original mathematical models that reflect the boom-type roadheader's body dynamics and its operational process. The operation of a cutting heads' inverter drive was reflected in the mathematical model used for computer studies. This allowed us to define the impact of the cutting heads' angular speed on the cutting process characteristics, roadheader's dynamic load, power demand during excavation, and energy consumption. The regulation characteristics obtained during these computer simulations show a correlation of the values describing the roadheader's dynamic load condition and efficiency of the cutting process to the parameters of this process. 


\section{COMPUTER SIMULATION OF DYNAMIC LOADS \\ IN ROADHEADER'S CUTTING SYSTEM}

Simulation studies covered the cutting process carried out with a roadheader equipped with a transverse cutting head inverter drive system. The excavation of rocks with different uniaxial compressive strengths (UCS) within a range of $20 \mathrm{MPa}$ to $70 \mathrm{MPa}$ and brittleness factor of $\kappa=15$ was examined. The lower cut was simulated, parallel to the floor and with different parameters for this process (Fig. 1).

Due to examining the possibility of controlling the angular speed of the cutting heads depending on the cutting process conditions, the motor shaft dynamic load characteristics in the cutting system and the angular speed obtained for different supply voltage frequencies (different angular speeds of cutting heads) were analyzed. While doing so, the cutting of rock with a uniaxial compressive strength of $R_{c}=60 \mathrm{MPa}$ during the making of a cut with a height of $h=200 \mathrm{~mm}$ and web $z=100 \mathrm{~mm}$ was simulated. The advancement speed $v_{O W}$ of the cutting heads was about $150 \mathrm{~mm} / \mathrm{s}$. Figure 2 shows the time characteristics mentioned above for two different angular speeds of the cutting heads. As seen above, this speed has a crucial impact on the magnitude and characteristics of the dynamic load. In the case of the lower angular speed $\left(\dot{\varphi}_{G}=5.54 \mathrm{rad} / \mathrm{s}\right.$, which corresponds to a motor supply voltage frequency of $f=30 \mathrm{~Hz}$ ) in the presented 3.5 second time interval, the cutting heads make three revolutions (a cutting head revolution period of $\left.T_{G}=1.13 \mathrm{~s}\right)$. The mean value of the dynamic load for the motor shaft $(M)$ was, in this case, $1344 \mathrm{Nm}$ (Fig. 2a - red line). It was, therefore, almost $60 \%$ higher than the nominal torque value of the motor in the cutting head drive of the roadheader being examined $\left(M_{n}=851 \mathrm{Nm}\right)$. The peak value and the amplitude of this load (understood as the range of dynamic load variation) had the following respective values: $3035 \mathrm{Nm}$ and $3305 \mathrm{Nm}$. The angular speed of the motor $(\dot{\varphi})$ oscillated within a range of $67 \mathrm{rad} / \mathrm{s}$ to $112 \mathrm{rad} / \mathrm{s}$, with an average value of approximately $90 \mathrm{rad} / \mathrm{s}$ (blue line). The increase of the cutting head angular speed to $9.24 \mathrm{rad} / \mathrm{s}(f=50 \mathrm{~Hz})$, with other cutting parameter values retained at a constant level, resulted in a decrease of about $15 \%$ of the motor shaft torque average value in the cutting system (Fig. 2b). Despite the lower value of the average load, the dynamic load variation range increased. The peak value and amplitude were $3282 \mathrm{Nm}(+8 \%)$ and $4544 \mathrm{Nm}(+38 \%)$, respectively. The angular speed of the motor was at that time oscillating within a range of $135 \mathrm{rad} / \mathrm{s}$ to $174 \mathrm{rad} / \mathrm{s}$, with an average value of approximately $154 \mathrm{rad} / \mathrm{s}$. During those $3.5 \mathrm{~s}$ simulations, the cutting heads made more than five revolutions (in this case, the cutting heads' revolution period was $T_{G}=0.68 \mathrm{~s}$ ).
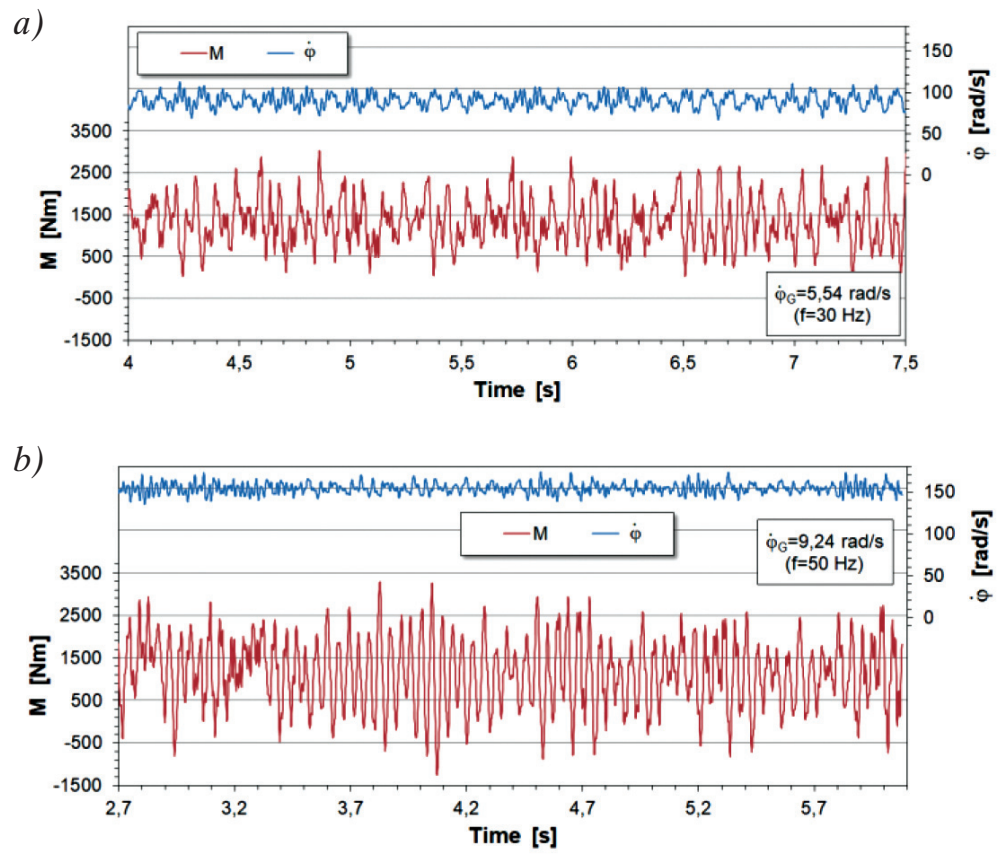

Fig. 2. Dynamic load characteristics of cutting head drive obtained in course of computer simulation of rock excavation with uniaxial compressive strength of $R_{c}=60 \mathrm{MPa}$ at angular speed of cutting heads of: a) $\left.\dot{\varphi}_{G}=5.54 \mathrm{rad} / \mathrm{s}(f=30 \mathrm{~Hz}) ; b\right) \dot{\varphi}_{G}=9.24 \mathrm{rad} / \mathrm{s}(f=50 \mathrm{~Hz})$ 
As shown by the exemplary characteristics, the angular speed of the cutting heads not only influences the magnitude but also the character of the dynamic load. The motor shaft torque characteristics during the cutting process are the result of summing the load characteristics caused by the interaction of picks with undisturbed soil. The load depends on the cutting geometry (size, shape, and sequence of cuts), which results from the speed of picks, among other things. In the case of the higher of the two angular speeds of the cutting heads $\left(\dot{\varphi}_{G}=9.24 \mathrm{rad} / \mathrm{s}\right)$, a beat effect is clearly visible. This phenomenon occurs due to the overlapping of vibrations with very similar frequencies [15]. The conducted spectral analysis of the motor shaft dynamic load characteristics in the cutting system for both examined angular speeds of the cutting heads showed the occurrence of two main components of vibrations (Fig. 3). For the cutting heads' angular speed of $5.54 \mathrm{rad} / \mathrm{s}$, these components have a frequency of $66.6 \mathrm{rad} / \mathrm{s}$ and $132.6 \mathrm{rad} / \mathrm{s}$ (Fig. 3a). The frequency of the first one is 12 times higher than the rotational frequency of the cutting heads (their angular speed). This results from the layout of the picks on the cutting head (the picks are placed along 12 helices with a small helix angle). It is, therefore, a helix frequency. The frequency of the second determined motor shaft vibration component is similar to one of the natural vibrations frequencies of the analyzed system. The increase of the cutting head angular speed (due to changing the motor voltage frequency of the cutting

a)

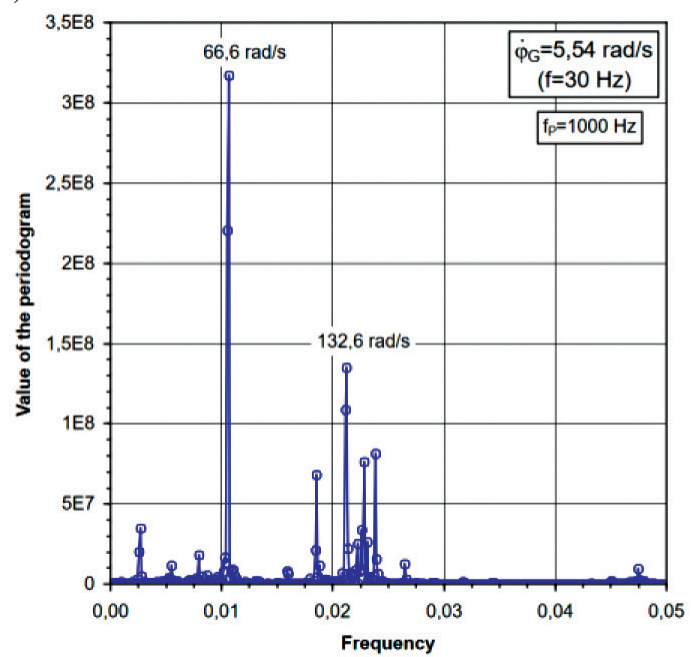

heads' drive) caused an increase in the helix frequency (Fig. 3b). In the case where $\dot{\varphi}_{G}=9.24 \mathrm{rad} / \mathrm{s}$, the value of this frequency is $110.6 \mathrm{rad} / \mathrm{s}$. The frequency of the second component of vibrations (138.2 rad/s) corresponds to, as previously, the natural vibration frequency of the examined roadheader's system. As seen above, the difference between the frequencies of the two vibration components is, in this case, just $27.6 \mathrm{rad} / \mathrm{s}$ $(\sim 4 \mathrm{~Hz})$. The result of similar frequencies of the dominant vibration components is the effect of the beat shown in Fig. 2b.

The dynamic character of the rock-cutting process causes the body of the roadheader (boom, turntable, main frame) and the boom deflection mechanisms to be exposed to strong forced vibrations transmitted via the constraints of particular components of the roadheader (Fig. 4). A particularly high variation is attributed to the dynamic load of the boom lifting actuators $P_{S P}$, which are responsible for keeping the cutting heads at the set height while they move in parallel to the floor. While excavating with a cutting head angular speed of $\dot{\varphi}_{G}=5.54 \mathrm{rad} / \mathrm{s}(\mathrm{red}$ line in Fig. 4a), the load had a range of -580 to $-123 \mathrm{kN}$ (minus means that these actuators are being extended while making a lower cut). The average value of this load is $-276 \mathrm{kN}$. An increase in the cutting head angular speed to $9.24 \mathrm{rad} / \mathrm{s}$ caused the dynamic load of the boom lifting actuators to drop by approximately $20 \%$ (Fig. 4b). In this case, the load changed within a range of $-510 \mathrm{kN}$ to $-61 \mathrm{kN}$ (with an average value of $-225 \mathrm{kN}$ ).

b)

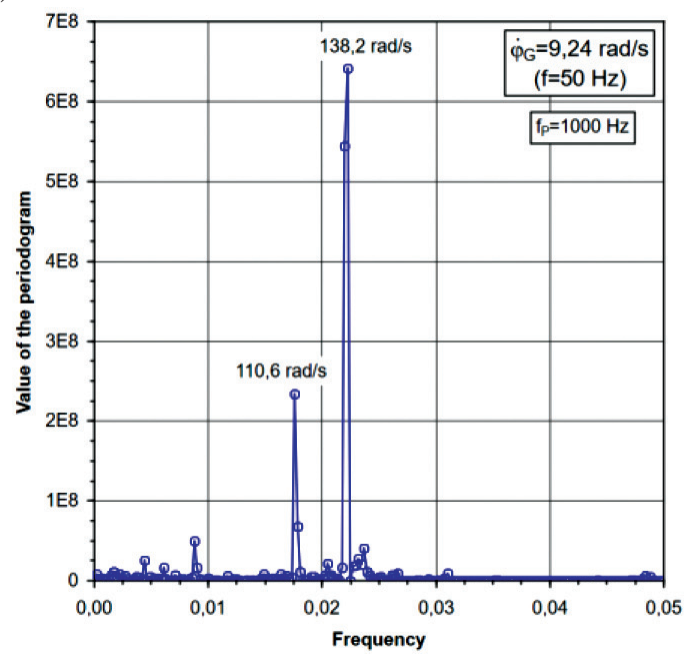

Fig. 3. Amplitude and frequency characteristics of motor shaft dynamic load in cutting heads' drive obtained in course of computer simulation of rock excavation at angular speeds of cutting heads of: a) $\dot{\varphi}_{G}=5.54 \mathrm{rad} / \mathrm{s}(f=30 \mathrm{~Hz} ; b) \dot{\varphi}_{G}=9.24 \mathrm{rad} / \mathrm{s}(f=50 \mathrm{~Hz})\left(f_{P}-\right.$ signal sampling frequency $)$ 
a)

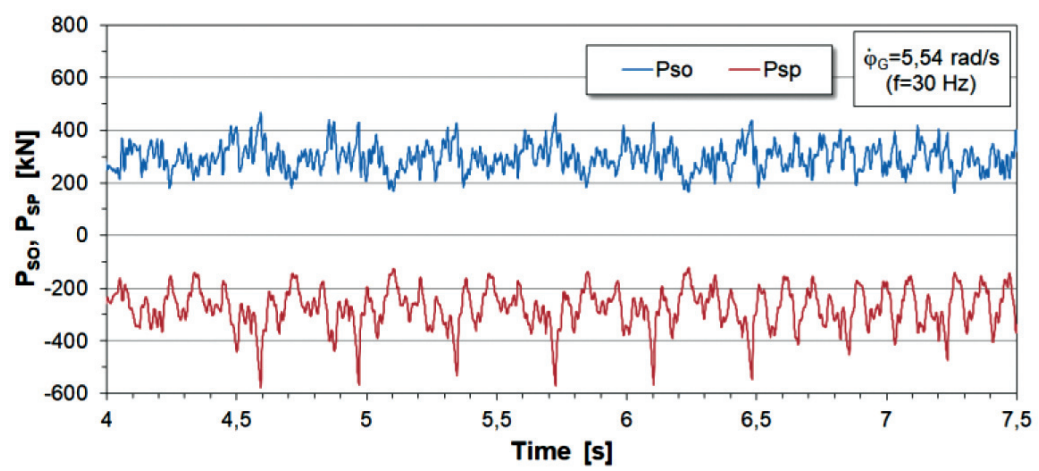

b)

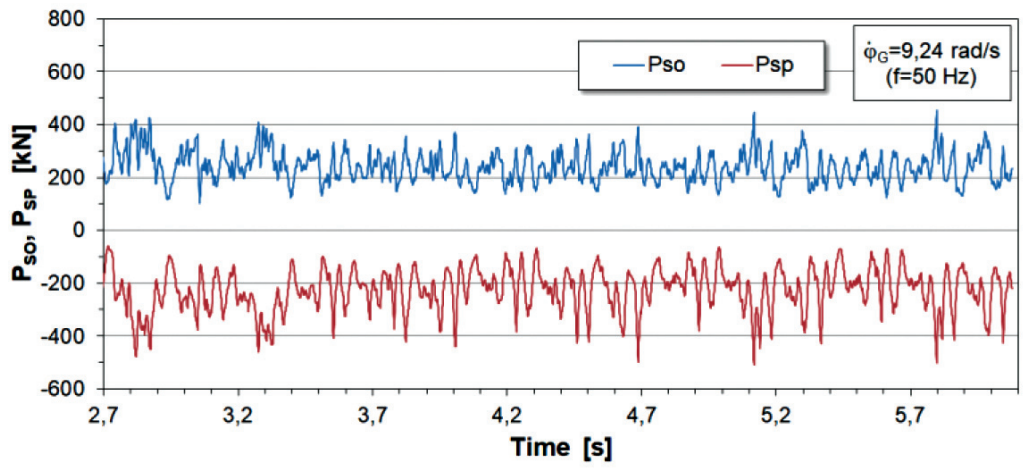

Fig. 4. Dynamic load characteristics of boom lifting and swing actuators obtained in course of computer simulation of rock excavation with uniaxial compressive strength of $R_{c}=60 \mathrm{MPa}$ at angular speed of cutting heads of: a) $\left.\dot{\varphi}_{G}=5.54 \mathrm{rad} / \mathrm{s}(f=30 \mathrm{~Hz}) ; b\right) \dot{\varphi}_{G}=9.24 \mathrm{rad} / \mathrm{s}(f=50 \mathrm{~Hz})$

In a similar way to the boom lifting actuators, the cutting head angular speed has a significant effect on the boom deflection mechanism actuators in a plane parallel to the floor $P_{S O}$ (blue lines in Fig. 4). For the smaller of the examined angular speeds of the cutting heads, the average value of this load was $296 \mathrm{kN}$ (Fig. 4a). An increase in the cutting head angular speed to $9.24 \mathrm{rad} / \mathrm{s}$ caused the average value of this load to drop by approximately $20 \%$ (Fig. 4b). Despite this, the dynamic load peak value of the boom swinging actuator did not change significantly, as it was $468 \mathrm{kN}$ for $\dot{\varphi}_{G}=5.54 \mathrm{rad} / \mathrm{s}$ and $454 \mathrm{kN}(-3 \%)$ for $\dot{\varphi}_{G}=9.24 \mathrm{rad} / \mathrm{sec}(-3 \%)$. The vibration amplitude of the dynamic load of the actuator in the boom swinging mechanism was $307 \mathrm{kN}$ for $\dot{\varphi}_{G}=5.54 \mathrm{rad} / \mathrm{s}$ and $350 \mathrm{kN}$ for $\dot{\varphi}_{G}=9.24 \mathrm{rad} / \mathrm{s}$ respectively. As seen above, an increase in the cutting head angular speed resulted in an increase in the dynamic load variation range for this mechanism. As with the dynamic load of the cutting head drive, one can also observe the influence of cutting head angular speed on the dynamic load characteristics of the boom deflection mechanisms here.

\section{INFLUENCE OF CUTTING PROCESS CONDITIONS ON DYNAMIC LOAD OF BOOM-TYPE ROADHEADER AND ENERGY CONSUMED DURING THIS PROCESS}

This chapter covers the issue of the proper adjustment of the cutting head movement speed during the cutting of rocks with particular UCS and with a set web and cut height. The angular speed of cutting heads $\dot{\varphi}_{G}$ and their advancement speed $v_{O W}$ have a significant influence on the dynamic load of the roadheader's cutting system and the energy consumed during the mining process (Figs. 5 and 6). In order to show the influence of rock workability on this type of load, rock cutting with a rather strongly differentiated uniaxial compressive strength $\left(R_{c}=20 \mathrm{MPa}\right.$ and $\left.70 \mathrm{MPa}\right)$ was examined. Computer simulations covered making the lower cut with a height of $h=200 \mathrm{~mm}$ and web of $z=100 \mathrm{~mm}$ with six different angular speeds of cutting heads $\dot{\varphi}_{G}$ and their advancement speed within a wide range of $40 \mathrm{~mm} / \mathrm{s}$ to $390 \mathrm{~mm} / \mathrm{s}$ (correlated to the technical capabilities of the examined roadheader). 
Due to the fact that the simulation studies covered an inverter drive system (equipped with a frequency inverter), the angular speed of the cutting heads correlates to the selected motor supply voltage frequency in their drive $f$. The applied frequency range $f$ of $25 \mathrm{~Hz}$ to $50 \mathrm{~Hz}$ corresponds to the angular speeds of the cutting heads within a range of $4.62 \mathrm{rad} / \mathrm{s}$ to $9.24 \mathrm{rad} / \mathrm{s}$ (Tab. 1). Due to the cutting head angular speed adjustment method, its particular values correspond to different values of drive motor output power. In the examined case, the output power of the motor in cutting system $N_{S}$ was within a range of $66 \mathrm{~kW}$ to $132 \mathrm{~kW}$, and the nominal torque of the motor was identical in all cases and had a value of $M_{n}=851 \mathrm{Nm}$.

\section{Table 1}

List of frequency set point values of motor supply voltage in cutting system and their corresponding angular speed of cutting heads and motor power of cutting head inverter drive system

\begin{tabular}{|c|c|c|}
\hline $\begin{array}{c}\text { Motor supply } \\
\text { voltage } \\
\text { frequency, } \boldsymbol{f} \\
{[\mathbf{H z}]}\end{array}$ & $\begin{array}{c}\text { Cutting head } \\
\text { angular speed, } \dot{\varphi}_{\boldsymbol{G}}\end{array}$ & $\begin{array}{c}\text { Motor power } \\
\text { in the cutting } \\
\text { system, } \boldsymbol{N}_{\boldsymbol{S}} \\
{[\mathbf{r a d} / \mathbf{s}]}\end{array}$ \\
\hline 25 & 4.62 & 66 \\
\hline 30 & 5.54 & 79 \\
\hline 35 & 6.47 & 92 \\
\hline 40 & 7.39 & 106 \\
\hline 45 & 8.32 & 119 \\
\hline 50 & 9.24 & 132 \\
\hline
\end{tabular}

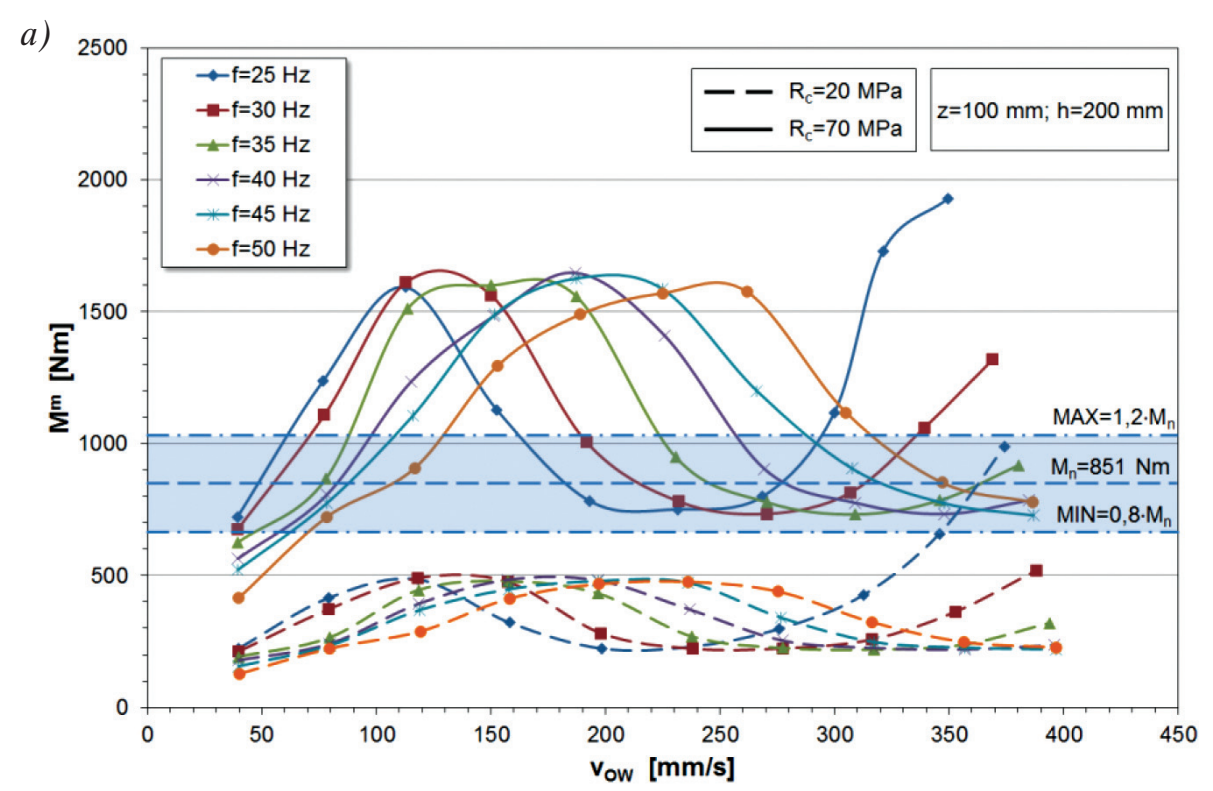

b)

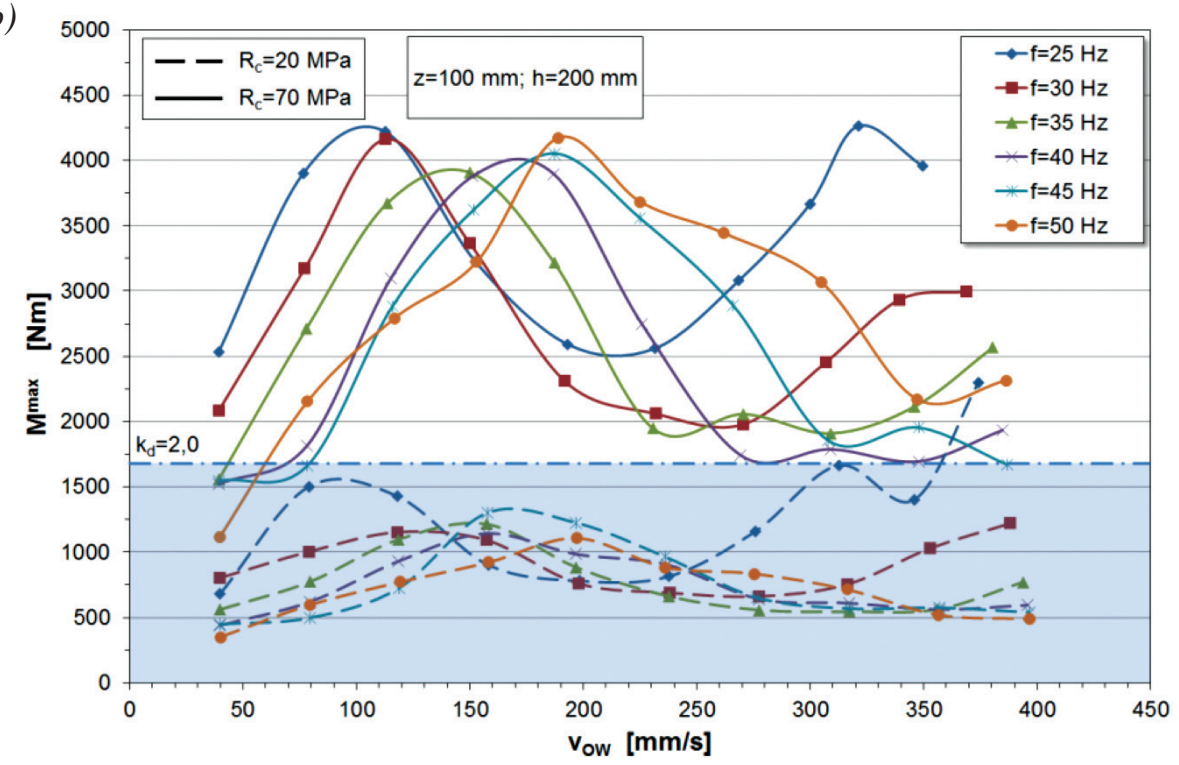

Fig. 5. Relationship of average value (a) and peak value (b) of dynamic load of motor in cutting system to angular speed of cutting heads (characterized by motor supply voltage frequency) and their advancement speed 

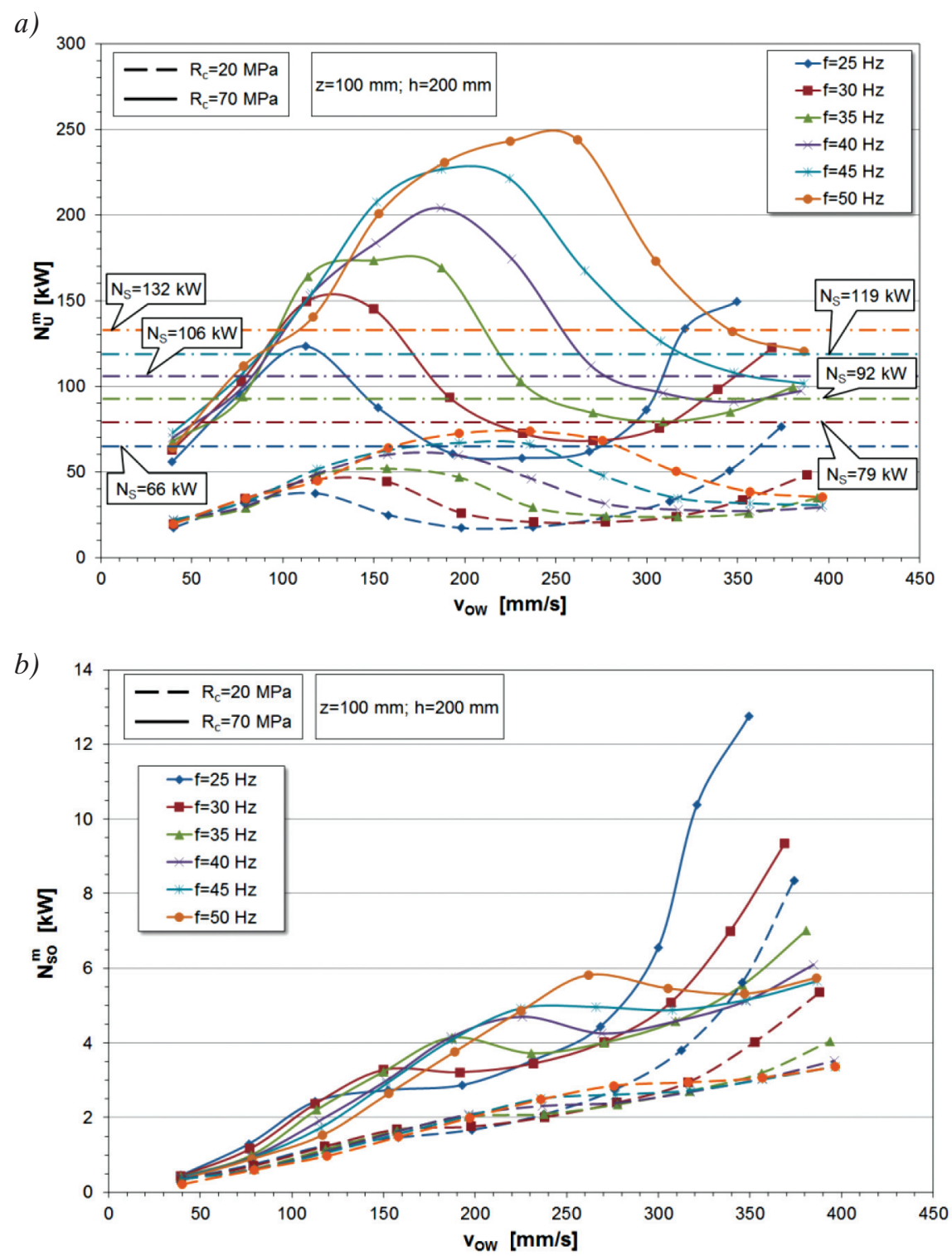

Fig. 6. Relationship of average value of power required for excavation (a) and average value of power used for deflecting boom (b) to angular speed of cutting heads (characterized by motor supply voltage frequency) and their advancement speed

The relationship between the parameters that characterize the dynamic load in the cutting system (the average $M^{m}$ and peak $M^{\text {max }}$ values) and the speed of the cutting heads (angular speed and their advancement speed) are complicated (Fig. 5). The characteristics of the examined functions show signs of the occurrence of extremes in the form of maximums and minimums. There are areas here where the cutting head drive is excessively dynamically loaded or even heavily overloaded. The dynamic load in certain speed ranges $v_{O W}$ can also reach a relatively low level. The extent of such ranges depends on the cutting heads' angular speed value $\dot{\varphi}_{G}$ (motor supply voltage frequency in the drive of the cutting heads' $f$ ). The value of this load depends heavily on mechanical properties of the excavated rock.

From the roadheader power optimization perspective, the choice of process parameter values is only beneficial when the average values of the dynamic load of the cutting head drive $M^{m}$ (determined in consecutive time intervals; e.g., every revolution of the cutting heads) have a similar value to the nominal value $M_{n}$ of the motor installed in the cutting system. Because cutting is not a stationary process, the average torque values of the motor shaft should be within a certain range of the nominal value; e.g., within a range of $0.8 M_{n}$ to $1.2 M_{n}$. When $M^{m}>1.2 M_{n}$, the drive of the cutting heads should be considered overloaded, 
and if $M^{m}<0.8 M_{n}$, the drive is underloaded [6]. Due to the dynamic character of the cutting process flow, operating with only an average value of load is insufficient. It is necessary to determine the allowable dynamic overload value of the drive. This is characterized by a dynamic overload factor $k_{d}$ that determines the allowable level of the dynamic overload peak value as related to the nominal value of the drive unit motor torque [5]. Considering the mechanical characteristics of the motor in the cutting head drive of the examined roadheader, the $k_{d}=2$ value was assumed.

In the case of processing rock with a UCS of $R_{c}=20 \mathrm{MPa}$, the average value of the dynamic load of the cutting head drive is, in fact, lower than $0.8 M_{n}$ in the whole variation range of the cutting head advancement speed and all their considered angular speeds (Fig. 5a-dashed lines). For the assumed web of the cut and cut height, the cutting system is highly underloaded. The peak values of this dynamic load do not exceed the allowable level defined by the dynamic overload factor $k_{d}$ (Fig. $5 \mathrm{~b}-$ dashed lines). The only exception is the case that corresponds to the lowest of the examined angular speeds (dark blue line) and the speed $v_{O W}$ greater than $300 \mathrm{~mm} / \mathrm{s}$ when the peak value of the dynamic load reaches (or even exceeds) the allowable value. In this case, the average power used for cutting by the cutting head drive does not exceed $80 \mathrm{~kW}$ at their highest angular speed (orange dashed line in Fig. 6a). The nominal motor output power for this angular speed is $N_{S}=132 \mathrm{~kW}$. It should be noted that, with an increase in the advancement speed of the cutting heads $v_{O W}$, the average power needed for cutting initially rises, and after reaching the maximum value - decreases. The maximum value of the average power used during cutting corresponds to different values of speed $v_{O W}$, depending on the angular speed of the cutting heads. The advancement speed of the cutting heads to which this maximum value corresponds are within a range of $120 \mathrm{~mm} / \mathrm{s}$ for $\dot{\varphi}_{G}=4.62 \mathrm{rad} / \mathrm{s}(f=25 \mathrm{~Hz})$ to approximately $240 \mathrm{~mm} / \mathrm{s}$ for $\dot{\varphi}_{G}=9.24 \mathrm{rad} / \mathrm{s}(f=50 \mathrm{~Hz})$. The average power needed for boom deflection in the plane parallel to the floor, at speeds $v_{O W}$ lower than $270 \mathrm{~mm} / \mathrm{s}$, increases more or less linearly with an increase in this speed (Fig. 6b - dashed lines). The impact of the angular speed of the cutting heads is, in this case, negligibly small. It becomes only noticeable at $v_{O W}>270 \mathrm{~mm} / \mathrm{s}$. At speeds $v_{O W}<270 \mathrm{~mm} / \mathrm{s}$, the power required for boom deflection does not exceed $3 \mathrm{~kW}$. At higher cutting head advancement speeds, it reaches $8.5 \mathrm{~kW}$ (for the lowest examined angular speed of the cutting heads).

During the excavation of rock with a uniaxial compressive strength of $70 \mathrm{MPa}$, the dynamic load of the cutting system is much higher (solid lines in Fig. 5). As seen above, this load significantly exceeds the assumed allowable levels for certain relationships of angular speeds of the cutting heads and their advancement speed. This particularly applies to the peak value of the motor shaft torque in the cutting system $M^{\max }$. Particular angular speeds of the cutting heads correspond to the speed $v_{O W}$ variation intervals in which the average value of this load is within the assumed limits (from $0.8 M_{n}$ to $1.2 M_{n}$ ) (Fig. 5a). For example, for $\dot{\varphi}_{G}=4.62 \mathrm{rad} / \mathrm{s}(f=25 \mathrm{~Hz})$, the average value of the motor shaft torque meets the above condition when the cutting head advancement speed does not exceed $60 \mathrm{~mm} / \mathrm{s}$ and is within a range of $165 \mathrm{~mm} / \mathrm{s}$ do $290 \mathrm{~mm} / \mathrm{s}$ (solid dark blue line). On the other hand, the cutting head advancement speeds (for which the average load is in the allowable range) are higher for the highest considered angular speed of the cutting heads (solid orange line). In this case, they are within a range of $65 \mathrm{~mm} / \mathrm{s}$ to $125 \mathrm{~mm} / \mathrm{s}$ and from $310 \mathrm{~mm} / \mathrm{s}$ to the maximum speed at which excavation is possible. The situation that applies to the peak value is completely different (Fig. 5b - solid lines). In fact, this does not exceed the assumed allowable level $\left(k_{d}=2\right)$ for only a cutting head advancement speed of $v_{O W}<80 \mathrm{~mm} / \mathrm{s}$ and their relatively high angular speeds (for $f=35 \mathrm{~Hz}$ ). For higher values of the speed $v_{O W}$ than the ones mentioned above, the drive of the cutting heads is significantly dynamically overloaded. In practice, this could mean that the cutting of the heading face surface in such conditions will not be possible. This is also indicated by the characteristics of the average power used for excavation by the cutting head drive (Fig. 6a-solid lines). For example, in the case of the highest-examined angular speed of the cutting heads (orange line) at their advancement speed of $110 \mathrm{~mm} / \mathrm{s}$ to $350 \mathrm{~mm} / \mathrm{s}$, the average power for cutting exceeds the output power of the motor by almost double (for a speed of $v_{O W}=\sim 250 \mathrm{~mm} / \mathrm{s}$ ). The increase of the average power necessary for deflecting the boom parallel to the floor is, in this case, not that significant (Fig. 6b - solid lines). In the examined case, the average power used by the boom deflection mechanism for speeds $v_{O W}$ that do not exceed $270 \mathrm{~mm} / \mathrm{s}$ reaches $6 \mathrm{~kW}$ (this is twice as high as compared to the power used during the excavation of rock 
with a UCS of $R_{c}=20 \mathrm{MPa}$ ). Within the range of higher speed $v_{O W}$ values and low angular speeds of the cutting heads, the average power used by this drive unit reaches $13 \mathrm{~kW}$ (at a nominal power of $11 \mathrm{~kW}$ of the pump-driving motor in the hydraulic system of the examined roadheader). For the excavation to be possible, it is therefore necessary to decrease the surface area of the cross-section of the cut (by reducing its height; alternatively - web depth).

The rock uniaxial compressive strength impact on the average value and peak value of the dynamic load of the cutting head drive is shown in Figure 7. The values of the parameters that characterize the dynamic load magnitude are correlated here to the nominal value of the torque of the drive unit motor $\left(M^{m} / M_{n}\right.$ and $M^{\max }\left(M_{n}\right)$. As seen above, when the UCS of the excavated rock mass increases, the average value of the dynamic load increases linearly (solid lines). The slope of straight lines (which reflect the characteristics of the functions examined herein) depends in this case on the cutting head advancement speed $v_{O W}$ at which the cutting process takes place (characterized by factor $k_{D O}$, which defines the opening magnitude of a directional control valve that supplies the fluid to the boom swing actuator). The influence of rock workability on the peak value of the dynamic load of the cutting head drive is, in this case, non-linear (dashed lines). For example, for $\dot{\varphi}_{G}=9.24 \mathrm{rad} / \mathrm{s}(f=50 \mathrm{~Hz})$ and depending on the cutting head advancement speed $v_{O W}$ (the value of factor $k_{D O}$ ), the relationship of $M^{m} / M_{n}$ is within a range of $(0.15 \div 0.5)$ for $R_{c}=20 \mathrm{MPa}$ to $(0.5 \div 1.9)$ for $R_{c}=70 \mathrm{MPa}$. In turn, the peak value of this load changes within a range of $(0.4 \div 1.3) M_{n}$ for $R_{c}=20 \mathrm{MPa}$ to $(1.3 \div 4.9) M_{n}$ for $R_{c}=70 \mathrm{MPa}$. Therefore, the increase of the rock uniaxial compressive strength in the examined range is accompanied by even a four-fold increase in the dynamic load of the cutting head drive.

\section{SUMMARY}

The selected results of the extensive computer studies presented in this article indicate an extremely complex impact of the cutting process parameters on the dynamic load of a roadheader when using the transverse cutting heads of the roadheader. The conducted simulation studies enabled us to correlate the cutting process parameters with the magnitude of the dynamic load in the cutting system and associated components of the roadheader, power used for excavation, and energy consumption of this process.

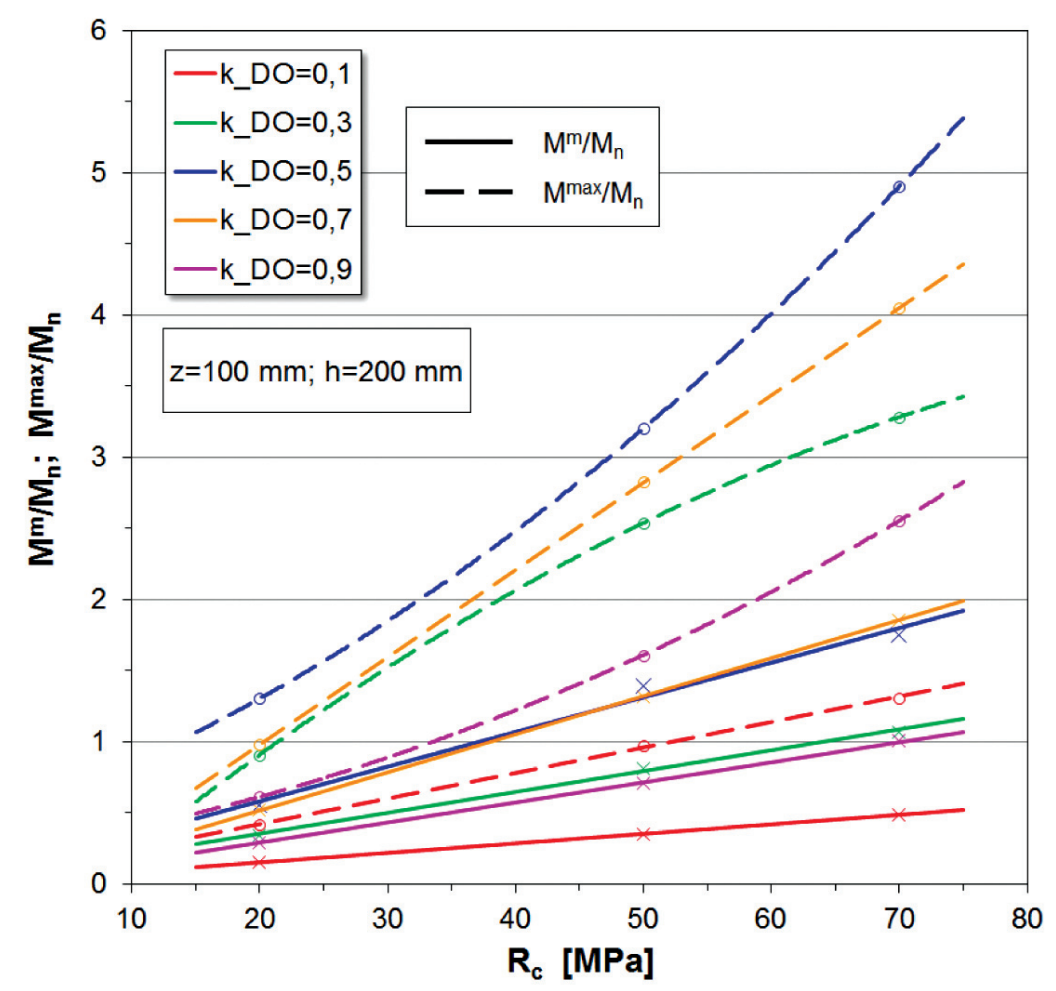

Fig. 7. Influence of processed rock's UCS on average value and peak value of dynamic load of motor in cutting head drive for different advancement speeds of cutting heads (determined by factor $k_{D O}$ ) at their angular speed

$$
\text { of } \dot{\varphi}_{G}=9.24 \mathrm{rad} / \mathrm{s}(f=50 \mathrm{~Hz})
$$


An important effect of the conducted studies is determining the influence of the angular speed of the cutting heads and their advancement speed over the heading face surface area on the dynamic load of the roadheader and the power demand for excavation. The resulting regulation characteristics of the roadheader indicate the possibility of reducing the dynamic loads exerted on the roadheader, power demand, and energy consumption of cutting rocks with specific mechanical properties by controlling the cutting process parameters, including the selection of the proper angular speed of the cutting heads and their advancement speed. By the correct adjustment of these values, it will be possible to effectively limit the occurrence of the dynamic loads exerted on the structural nodes of the roadheader's body and ensure a high efficiency of mining, which is a prerequisite for minimizing energy consumption during this process. This will lead to an increase in working efficiency of this type of machine and the improvement of its durability and reliability.

\section{Acknowledgement}

The work has been implemented under the research project titled "Control of roadheader cutting heads movement for reduction of energy consumption of mining and dynamic loads" co-financed by the Polish National Center for Research and Development under the Applied Research Projects (agreement no. PBS3/B2/15/2015).

\section{References}

[1] Bartoszek S.: Pozycjonowanie kombajnu chodnikowego w wy robisku korytarzowym, "Maszyny Górnicze" 2016, 1: 22-35.

[2] Bickel J.O., Kuesel T.R., King E.H. et al.: Tunnel Engineering Handbook, Kluwer Academic Publishers, Boston - Dordrecht - London 2004.

[3] Catalina J.C., Artieda J., García A.E., Orteu J.J., Devy M. Mańana R.: Recent developments on the use of computer vision as a face mapping tool, in: Mine Mechanization and Automation, ed. Almgren G., Kumar U., Vagenas N. et al., Wydawnictwo Balkema, Rotterdam 1993: 555-564.

[4] Cheluszka P., Sobota P., Bujnowska A.: Bench testing of the influence of operating parameters of cutting heads on energy consumption of cutting with roadheader, "Technická Diagnostika" 2017, 1: 75-86.

[5] Dolipski M., Cheluszka P.: Dynamika układu urabiania kombajnu chodnikowego, Wydawnictwo Politechniki Śląskiej, Gliwice 2002.

[6] Dolipski M., Cheluszka P., Sobota P.: Investigating the simulated control of the rotational speed of roadheader cutting heads, relating to the reduction of energy consumption during the cutting process, "Journal of Mining Science" 2015, 2: 298-308.
[7] Dolipski M., Cheluszka P., Sobota P., Bujnowska A.: Komputerowe badania wpływu parametrów ruchowych głowic urabiajacych na obciążenie układu urabiania kombajnu chodnikowego, "CUPRUM - Czasopismo Naukowo-Techniczne Górnictwa Rud" 2015, 3: 131-142.

[8] Jasiulek D., Stankiewicz K., Swider J.: An adaptive control system of roadheader with intelligent modelling of mechanical features of mined rock, "Journal of KONES Powertrain and Transport" 2011, 2: 197-203.

[9] Jonak J., Gajewski J.: Robotyzacja maszyn roboczych na przykładzie kombajnu chodnikowego, "Transport Przemysłowy i Maszyny Robocze" 2011, 4: 66-69.

[10] Karaś H.: Why robotics in mining?, International Conference on New Technologies and Policies for Mining and Mining Products "Pushing boundaries beyond - Circular by 2020?", Dublin; $9^{\text {th }}$ March 2015, http://www.euromines.org/system/ files/events/pushing-boundaries-beyond-circular-2020/08henryk-karas.pdf.

[11] Kotwica K., Klich A.: Maszyny i urzadzenia do drą̇enia wyrobisk korytarzowych $i$ tunelowych, ITG KOMAG, Gliwice 2011.

[12] Larsson J., Appelgren J., Marshall J., Barfoot T.: Atlas Copco Infrastructureless Guidance System for High-Speed Autonomous Underground Tramming, Proceedings of 5th International Conference and Exhibition on Mass Mining, 2008: $585-594$.

[13] Nanda S.K., Dash A.K., Acharya S., Moharana A.: Application of robotics in mining industry: A critical review, "The Indian Mining \& Engineering Journal” 2010: 108-112.

[14] Ocak I., Bilgin N.: Comparative studies on the performance of a roadheader, impact hammer and drilling and blasting method in the excavation of metro station tunnels in Istanbul, "Tunnelling and Underground Space Technology" 2010, 2: 181-187.

[15] Starczewski Z.: Drgania mechaniczne, Wydawnictwo Politechniki Warszawskiej, Warszawa 2010.

[16] Su Hang, Ning Shurong, Gao Jun: Application of Approximate Iterative Method on Section Precision Forming of Boom type Roadheader, "The Open Automation and Control Systems Journal" 2015, 7: 1421-1428.

[17] Vogt D.: A review of rock cutting for underground mining: past, present, and future, "Journal of the Southern African Institute of Mining and Metallurgy" 2016, 116, 11: 1011-1026.

[18] Ziętkowski L., Młynarczyk J.: Mechaniczne urabianie skat zwięzłych kombajnami w kopalniach KGHM Polska Miedź S.A., "Inżynieria Maszyn" 2014, 19, 2: 17-27.

[19] http://www.power-technology.com/projects/tapovan-vishnugad-hydroelectric-power-plant-uttarakhand/.

[20] http://www.nvfnorden.org/library/Files/Utskott-och-tema/ Tunnlar/Seminarier-2012-2016/ITA-Island-2015NF Oct $\% 2029$ _Canada_\%20East\%20and\%20West\%20Overview.pdf.

PIOTR CHELUSZKA, assoc. prof. MARIAN DOLIPSKI, prof. PIOTR SOBOTA, Ph.D., Eng. Department of Mining Mechanization and Robotisation Faculty of Mining and Geology Silesian University of Technology ul. Akademicka 2, 44-100 Gliwice, Poland \{Piotr.Cheluszka, Marian.Dolipski, Piotr.Sobota\}@polsl.pl 